\section{Cureus}

Received 01/14/2013

Review began 01/15/2013

Published 06/06/2013

C) Copyright 2013

Prolo et al. This is an open access article distributed under the terms of the Creative Commons Attribution License CC-BY 3.0., which permits unrestricted use, distribution, and reproduction in any medium, provided the original author and source are credited.

\title{
Efficacy and Safety of Ethylene Oxide Sterilization of Allogeneic Bone for Human Transplantation: A Forty-Year Experience
}

\author{
Donald J. Prolo ${ }^{1}$, Sally K. Oklund ${ }^{2}$, Mark Borer ${ }^{3}$
}

1. Department of Neurosurgery, Stanford University School of Medicine 2. Western Transplantation Services, San Jose, CA 3. Western Transplantation Services, San Jose, CA; California Transplant Donor Network, Oakland, CA

$\square$ Corresponding author: Donald J. Prolo, don@donaldprolo.com

Disclosures can be found in Additional Information at the end of the article

\section{Abstract}

Context: Since the year 2000, allogeneic tissues utilized for operations in humans in the United States have commonly undergone terminal sterilization with gamma irradiation. Ethylene oxide sterilization of tissues processed for human implantation has been abandoned

Objectives: (1) To record the long-term successful experience of a precursor transplantation laboratory in the provision of human bone and fascia sterilized with "cold cycle" ethylene oxide; (2) to report the successful experience of a single neurosurgeon operating in a community hospital using only this bone to fuse and stabilize the lumber spine without instrumentation; (3) to review historic and contemporary scientific evidence for the biologic and biomechanical effects of ethylene oxide gas and gamma irradiation exposure on tissues, along with their virucidal, fungicidal and bactericidal properties for surface and interstitial sterilization.

Design: Records from the Western Transplantation Services (WTS) laboratory were scrutinized documenting the 18 years of its existence (1978-1996) as well as the voluminous, carefully preserved records of patient interactions, preoperative, operative, and postoperative records archived over three decades from 321 patients undergoing 339 operations by a single neurosurgeon utilizing 1,135 tricortical iliac crest wedges sterilized with ethylene oxide.

Main Outcome Measures: Rates of infection and neoplasia in allograft recipients or in laboratory personnel from preparation and distribution of over 50,000 ethylene oxide sterilized allografts provided by a single processing laboratory; lumbar spine fusion rate and complications attributable to grafts among patients receiving these implants.

Results: Over 50,000 allografts distributed from Western Tranplantation Services resulted in no reported infections or neoplasia in any recipient and no neoplasia among technicians processing four tissues with exposure to ethylene oxide. Fusion rate among patients undergoing uninstrumented posterior lumbar interbody fusion (PLIF) with tissues distributed by this laboratory was $96 \%$ with no reported infections and no allograft fractures. Complication rate of $4 \%$ related to the operation and not the performance of the allografts processed by the laboratory.

Conclusions: Ethylene oxide sterilization of allogeneic tissues for human transplantation is a safe, efficacious method and merits reconsideration as a remarkably unique surface and interstitial tissue sterilant that is bactericidal, fungicidal and virucidal without compromise of

How to cite this article

Prolo D J., Oklund S K., Borer M (June 06, 2013) Efficacy and Safety of Ethylene Oxide Sterilization of Allogeneic Bone for Human Transplantation: A Forty-Year Experience. Cureus 5(6): e121. DOI 10.7759/cureus.121 
Categories: Miscellaneous, General Surgery, Neurosurgery

Keywords: osteoinduction, osteoconduction, transplantation, tissue transplantation, tissue banks, ethylene oxide sterilization, irradiation sterilization, human allografts, lumbar fusion, bone remodeling

\section{Introduction}

Neurological and orthopedic surgeons often utilize bone grafts to restore the structural integrity and stability of the spine. Whereas fresh autogeneic bone is regarded as the "gold standard" for conveying immunologically identical living cells, bone collagen, inductive proteins, and mineral to the host bed, harvesting a large enough quantity of autografts usually requires another incision to obtain iliac crest or other sources of bone. This secondary donorsite wound can be associated with at least ten complications complicating the recovery, to include problems in wound healing, hemorrhage/blood loss/anemia, massive hematoma, deep wound infection, iliac hernia, pelvic instability, fatigue fracture, heterotopic bone formation, lateral femoral cutaneous nerve injury (meralgia paresthetica), and chronic severe donor site pain. In one large series of 239 patients, autogeneic bone grafting resulted in major (8.6\%) and minor (20.6\%) complications totaling 29\% [1]. Consequently, a reliable, sterile human bone allograft with capacity for filling defects and furthering new replacement bone formation at the orthotopic graft site offers an inviting replacement hard tissue capable of fulfilling goals of the surgeon.

William Macewen (1848-1924), a Glasgow physician, in 1878 was the first surgeon to transfer a free bone allograft. Allograft blocks were removed from two young living donors to correct their deforming anterior tibial curves and successfully used to replace a large section of humerus destroyed by suppuration in a four-year-old recipient [2].

Allogeneic bone is more commonly transplanted in humans than any other tissue or organ with the exception of blood. Whereas in 2001, 13,898,000 units of whole blood and packed cells were transfused into 4,900,000 recipients in the United States, in 2007 countrywide tissue banks distributed 1.5 million human tissue allografts [3-4]. The procurement, processing, preservation, and utilization of allogeneic human tissue for surgical procedures must follow the scrupulous screening and testing of suitable human donors, adherence to rigid protocols for insuring the sterility and integrity of the processed alloimplants, and optimal methodologies for storage and distribution prior to its use [5]. Two major hurdles to the maximal availability and utilization of human bone allografts for clinical application have been the following: (1) confirmation of sterility of the implant after aseptic procurement or following terminal sterilization, and (2) effective preservation of the physical integrity and biological potency of implants distributed for use in diverse environmental temperatures and for various medical indications over space and time. Maximal availability of human bone for surgeons is increased by the possibility of tissue processing laboratories acquiring human allogeneic bone in clean but non-sterile environments, thereafter employing safe, effective techniques for terminal surface and interstitial sterilization of grafts, and developing preservative and packaging methods that allow distribution and use of tissues without compromising sterility.

Although blood banks had existed for years, formal banking of tissues other than blood began in 1950 at the United States National Naval Medical Center, Bethesda, Maryland, under the direction of G.W. Hyatt [6-7]. In the United States, tissue banks followed first at the University of Miami in 1972 [8] and then at the Northern California Transplant Bank (NCTB), Institute for Medical Research, Santa Clara Valley Medical Center, San Jose, California, in 1973 [9]. 
NCTB was the third tissue bank in the United States to procure, process, store, and distribute multiple human tissues and products. In 1980, NCTB moved to San Francisco. The component bank for bone, dura mater, fascia, and tendons, the NeuroSkeletal Transplantation Laboratory (NSTL) and its successor laboratory in 1988, Western Transplantation Services (WTS), remained at the Institute for Medical Research in San Jose.

Research at NSTL in the mid-to-late 1970s led to the clinical use of ethylene oxide (EO) for terminal surface and interstitial sterilization of human bone, fascia, and dura mater. A comprehensive series of experiments was serially described in a 1980 publication in the journal, Neurosurgery, the first report validating the effectiveness of sterilization of tissues with EO and the subsequent removal of that chemical and its byproducts EC and EG from tissue [10].

When results of this investigation were published in 1980, use of EO

sterilized/lyophilized/allogeneic bone and soft tissues for restorative operations in humans was in its infancy. Over the decades, tens of thousands of patients have received allogeneic bone treated according to this protocol. Now validation of the method over a 40 -year period follows. First, an extensive experience at our laboratory between 1978-1996 is herein reported, using this methodology for graft procurement, processing, and distribution for application in humans. From laboratory records, documentation is presented of EO's effectiveness in sterilizing tissues and of its safety both for use in patients and for occupational exposures to laboratory personnel. Second, the efficacy and safety for use of grafts prepared by this technique of allograft processing is confirmed for humans in an extensive, carefully followed group of 321 patients undergoing 339 lumbar fusion operations and utilizing 1,135 allogeneic, iliac crest, tricortical wedge blocks between 1981-2006 (manuscript in preparation).

\section{List of abbreviations}

$\begin{array}{ll}\text { AATB } & \text { American Association of Tissue Banks } \\ \text { CTDN } & \text { California Transplant Donor Network } \\ \text { EC } & \text { ethylene chlorohydrin } \\ \text { EG } & \text { ethylene glycol } \\ \text { EO } & \text { ethylene oxide } \\ \text { FDA } & \text { US Food and Drug Administration } \\ \text { HIV } & \text { human immunodeficiency virus } \\ \text { kGy } & \text { kiloGray } \\ \text { NCTB } & \text { Northern California Transplant Bank } \\ \text { NSTL } & \text { NeuroSkeletal Transplantation Laboratory } \\ \text { OPO } & \text { Organ Procurement Organization } \\ & \\ \text { SAL } & \end{array}$




\section{Materials And Methods}

\section{Tissue bank laboratory procedures}

NSTL/WTS in San Jose, CA provided human bone allografts for operative procedures for 23 years, from 1973-1996. During this time, tissue banking was a rapidly growing service in the United States. NSTL/WTS complied with the evolving standards and practices (donor selection, tissue procurement and processing, terminal sterilization, lyophilization preservation, and accountable distribution) promulgated by the American Association of Tissue Banks, the certifying organization for tissue banks [5].

\section{Tissue donor identification, screening and consenting}

The tissue bank independently established a donor network of hospitals and coroner offices in Northern and Central California as sources of tissues. Following passage of the National Organ Transplantation Act in 1984, the laboratory in 1985 participated with other Northern California transplantation entities in establishing the California Transplant Donor Network (CTDN). This Organ Procurement Organization (OPO) served as a central regional resource for initially identifying and screening donors of organs and tissues. Causes of death of potential donors were determined, along with rigorous historical screening from decedents' families and caregivers for the presence of potentially communicable diseases, which excluded donorship. Individuals expiring from neoplastic conditions, infections, age greater than 55 years for bone and 75 years for soft tissues or from unknown cause(s) were also excluded. An identified legal next-of-kin family member was apprised of the possibility of tissue donation. Absent objections from immediate relatives, technicians acquired authorizations for removal of tissues.

\section{Tissue procurement}

Tissues were only removed by American Association of Tissue Banks (AATB) Certified Tissue Bank Specialists from meticulously screened donors. Tissues were removed within a few hours of death or from those who were maintained postmortem at $2^{\circ}-8^{\circ} \mathrm{C}$ for up to 24 hours in hospital morgues. Pelvic and lower extremity bones were removed in a clean, non-sterile environment and replaced with artificial implants designed to maintain cosmetic integrity of the decedent. Tissues were wrapped twice with surgical towels and placed in plastic bags. Blood was obtained for serological testing.

\section{Initial laboratory processing}

Bone and soft tissues from each donor were processed separately from those of any other donor. Thus, all tissue derived from each donor was considered one definable lot. Technicians placed bone in a $-70^{\circ} \mathrm{C}$ freezer, a preservative environment well below the eutectic temperature of bone established as $-28^{\circ} \mathrm{C}$. Ultra-low temperature storage allowed delay in further processing up to a few months, or pending return of results from all serological testing for Human Immunodeficiency Virus (HIV), hepatitis A, B and C antigens and/or antibodies, and syphilis. Evidence for any transmissible disease disqualified donor tissue from further processing. Subsequently, in the case of bone, adherent soft tissues were removed with scalpels and rongeurs. Bone was cut into various sizes and shapes in accordance with surgical requirements. A high-pressure filtered water stream was directed at surface and bone marrow sites on and within grafts to purge cellular residues from bone that mediate immune responses and to reduce chloride ion substrates which later could form ethylene chlorohydrin during the sterilization step. Further, the vigorous washing technique removed cellular debris from the bony scaffold to open cancellous pathways for revascularization and remodeling 
(osteoconduction). Structural grafts were further trimmed, followed by a second nonpressurized washing with deionized water. Tissue was then optionally stored at $5^{\circ} \mathrm{C}$ temporarily or immediately sterilized.

\section{Sterilization with gaseous ethylene oxide}

Crafted allografts were placed individually in thick-walled bottles, loosely capped with heavy rubber stoppers designed with two wide slits at 180 degrees of each other at the lower third of the round stopper to allow entry/exit of EO. Bottles were coded to identify the tissue therein. Multiple bottles of allografts were placed on a tray, wrapped with surgical towels, inserted into a "cold" vacuum cycle EO sterilizer, operating initially at $29.4^{\circ} \mathrm{C}$, then subsequently over the years at $37^{\circ} \mathrm{C}$. for 5.5 hours (3M 4 XL Sterivac). The colder cycles were used to avoid exposing and denaturing the tissues in the higher temperature sterilizer operating at $55^{\circ} \mathrm{C}$. Tissues were then frozen to $-70^{\circ} \mathrm{C}$ again after EO sterilization.

\section{Freeze-drying (lyophilization)}

Tissues were then lyophilized for 72-120 hours to reduce the residual water content to less than $5 \%$ of the original wet weight and concomitantly to remove EO, EG, and EC to within FDA recommended levels [11]. Within the freeze-drier after lyophilization, the thick-walled bottles containing the lyophilized, sterilized allografts were stoppered under vacuum for indefinite preservation of that allograft at room temperature with expiration date set at five years. A metallic cap was placed over the rubber stopper for protection during distribution.

After each lyophilization run consisting on average of six to eight donors and about 140 allografts, certified technicians sent tissue samples to a commercial laboratory for determination of residual water content and levels of EO, EG, and EC. All tissues were to be discarded if samples exceeded acceptable levels, but tissue levels invariably were below FDAproposed Residue Limits in Implanted Devices [11].

A parallel series of expendable allografts in stoppered bottles were subjected to identical processing with those allografts prepared for distribution. These grafts, representing $10 \%$ of the total number of processed tissue implants, underwent microbiological cultures in compliance with guidelines stipulated in the United States Pharmacopeia for a batch size of 200 or less. At least two different bacteriological culture media were used with each monitorial implant to validate sterility of the lot of tissues from one donor. Presence of bacteria on any culture resulted in discarding the entire lot of bone and other tissues from a single donor. Bacteriostasis during culture of tissues due to low EO residues in the allografts remained a possibility; however, absence of any report of an infection from over 50,000 distributed allografts tended to negate that possibility and validated the method of sterilization and monitoring after processing (see Discussion).

\section{Distribution}

Freeze-dried EO-sterilized allografts in evacuated bottles were distributed at environmental temperatures throughout the United States. A questionnaire accompanied each distributed allograft, requesting reports from surgeons or hospital staffs regarding perioperative adverse events occurring from use of the grafts, including infections, neoplasms, or graft imperfections, in order to implement quality control of the allograft product.

\section{Utilization}

Instructions for rehydrating and removing tissues accompanied each bottled graft. Using sterile techniques, surgeons rehydrated the bone or soft tissues with normal saline within the vacuum- 
sealed bottles, thus insuring imbibition of saline into the interstices of the lyophilized hard or soft tissues. Over 50,000 crafted bone allografts, cancellous bone deposits and soft tissues were distributed throughout the United States to over 200 hospitals in 28 states.

\section{Posterior lumbar interbody fusions using allogeneic bone}

The senior author, with other surgeons, performed all posterior lumbar interbody fusions, following a technique first reported by Cloward in 1945 and published in 1953 [12], in which tricortical wedge-shaped iliac crest block allografts were impacted into the evacuated intervertebral disc space. In summary, after a generous posterior exposure by bilateral laminotomies of spinal arches with preservation of at least half of bilateral facet joints and removal of ligamenta flava overlying caudal dura mater and lower elements of the cauda equina, the soft disc was totally removed from bilateral approaches. Upper and lower cortical endplates of adjacent vertebrae were partially removed to allow cancellous bone of the allograft to be in immediate contact with cancellous bone of the two adjoining vertebrae, thus implementing osteoconductive revascularization and remodeling of the implanted allografts with osteoprogenitor cells from adjacent lumbar vertebrae. Iliac crest wedge allografts were positioned vertically within the evacuated intervertebral disc space, parallel to the transverse (axial) plane. The entire disc space was filled with allografts, all recessed 3-5 mm in front of the posterior margins of the vertebral bodies.

Because of the extensive nature of the procedure with several hours of surgical exposure, measures were directed against bacterial contamination of the wound. Two shoulder-tobuttocks back scrubs with Betadine disinfectant soap for 10 minutes each were administered after arrival of the patient to the preoperative admission facility. At onset of anesthesia, $1 \mathrm{gm}$ of intravenous cefazolin was delivered. During and at the conclusion of the operation, the open wound was frequently irrigated with saline, and at the end of the procedure 50,000 units of bacitracin in 50-ml. saline was instilled in the wound. Postoperatively, $1 \mathrm{gm}$. cefazolin was delivered intravenously every eight hours for three doses.

Three hundred and twenty-one (321) patients underwent 339 PLIF operations. Patients undergoing 325 of 339 PLIF operations (96\%) were evaluated at a minimum of one year postoperatively with some as long as 24 years after the operation in order to determine their fusion rates, their functional/economic recovery rates, and their long-term courses (this comprehensive report in preparation). For this extensive retrospective review of patients precise clinical histories, voluminous preoperative, operative, and postoperative records as well as radiographic imaging studies were maintained for the 321 patients over a 31-year period. Data was methodically transcribed from patient charts onto worksheets and then inputted into Microsoft Excel spreadsheets, collated, and analyzed.

At three-month intervals during the first postoperative year, lateral and anterior-posterior (AP) lumbar spine X-rays were used to follow progress of the fusion. After one year, lateral and A$\mathrm{P}$ bending $\mathrm{X}$-rays were performed and then also usually at two years, especially if there was a question about status of the fusion or continuing pain. When questions arose as to the presence of a successful fusion in later years of the series, CT helical scans of the lumbar spine with $0.625 \mathrm{~mm}$ slice axial images reformatted in coronal and sagittal planes became available and were ordered to demonstrate in a fused motion segment cancellous bone passing through the allografts from the upper and lower vertebral bodies. Multiple independent radiologists over the years determined presence or absence of fusion, never the operating surgeons.

\section{Results}

\section{Complications and safety for patients and technicians of bone}




\section{allografts distributed from Western Transplantation Services Laboratory}

Over the 18 years from 1978 to 1996, the NSTL/WTS laboratory and medical director then or subsequently received no reports of adverse reactions, neoplasms or infections related to allografts from surgeons who utilized over 50,000 ethylene oxide sterilized/lyophilized human bone and soft tissue allografts. Concerns of causing neoplasms in patients from residual EO, EC, and EG in grafts and in technicians from exposures to EO during sterilization processing have been assuaged by absence of any reported cases of neoplasia in tens of thousands of recipients and decades of EO exposure and processing by certified technicians.

At least 50 percent of the reporting questionaires were returned. The laboratory was never notified of an alloimplant causing an infection, neoplasm, or graft imperfection through any form of communication. Consumer, hospital, user-surgeon, and societal awareness, expectations and demands of product safety together strengthen reliability of absolutely no reports of tissue-caused infections or neoplasia among patient recipients (see Discussion).

\section{Clinical safety and efficacy of allografts utilized in large series of patients undergoing posterior lumbar interbody fusion (PLIF)}

Over the twenty-five years from 1981 to 2006, 321 unique patients underwent 339 PLIFs with intradiscal placement of iliac crest wedges of human allogeneic bone. Fourteen patients in the series had two PLIF procedures on separate dates, and two patients had three separate PLIF operations over time. The fusion rate was determined for 308 patients undergoing 325 PLIF operations. Thirteen patients were not followed for one full year after their PLIF operation.

Among 277 patients, 294 single-level PLIF operations were performed and followed for one year or more. Their fusion rate was $96 \%$ (fused 281/non-fused 13). An additional 31 patients who underwent a two-level PLIF operation were followed for one or more years. Ninety-eight percent (98\%) of these 62 levels fused (fused 61/non-fused 1). The combined fusion rate for one- and two-level PLIF operations was $96 \%$.

There were no perioperative deep wound infections among the full total of 339 PLIF operations. A grand total of 1,135 alloimplants were positioned in the 371 intervertebral disc spaces, averaging 3.1 iliac crest blocks per space. Two blocks from an outside tissue processing center fractured and migrated, requiring a second operation to remove and replace the grafts. Grafts were remodeled from adjacent vertebrae by revascularization, osteoclastic resorption followed by appositional new bone formation (Figures 1,2). Failure of fusion of an alloimplant with the contiguous host vertebral body in patients with pseudarthroses occurred at either the superior or inferior interface with the adjacent vertebra, rarely both. There were no instances of neoplasia reported in any patient recipient proximal to or remote from the allografts, resulting from possible EO, EC, or EG residuals. 


\section{Cureus}

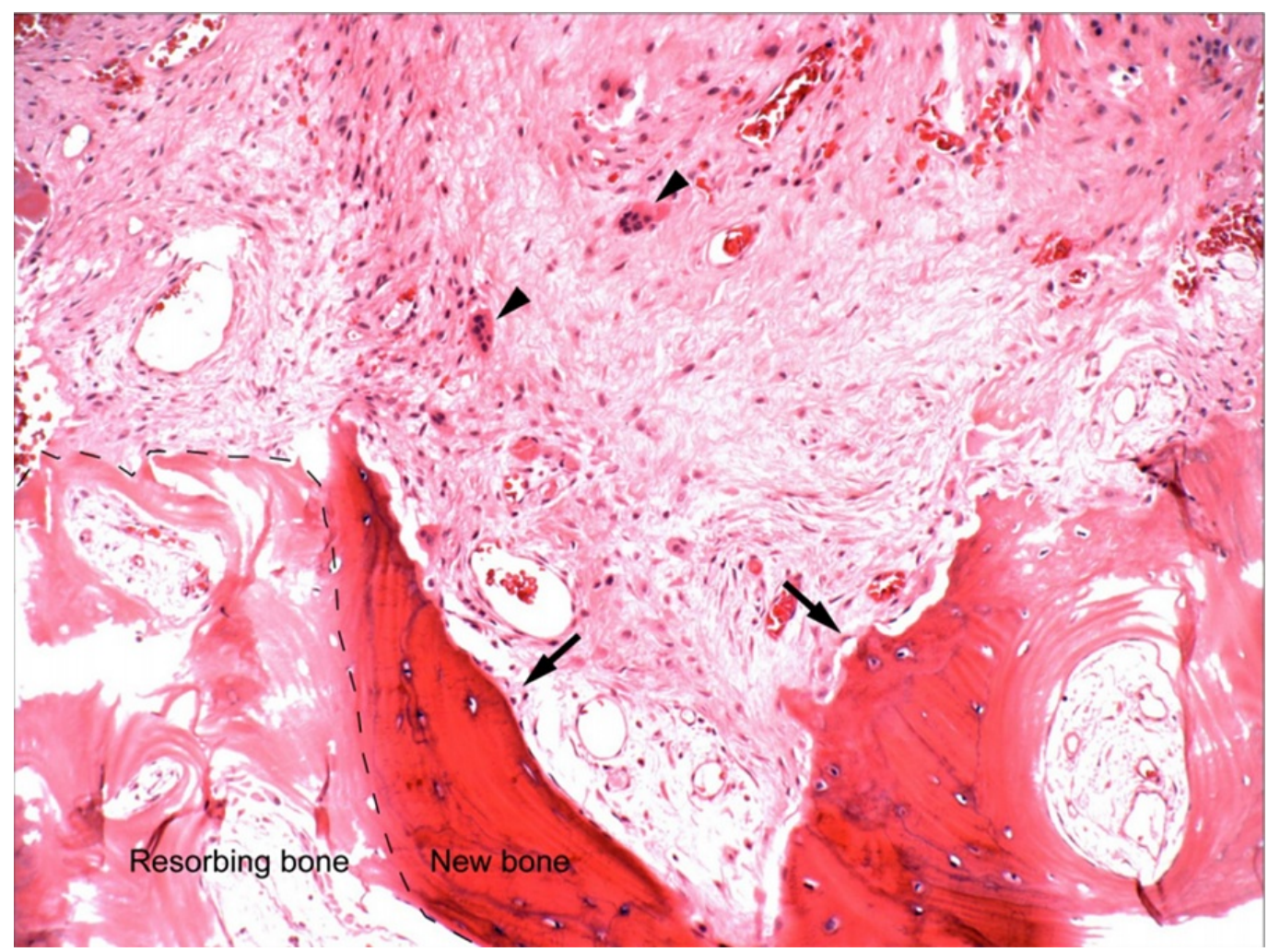

FIGURE 1: Bone Remodeling in Allograft, 200x magnification

A biopsy specimen from the residual allograft within the $L 4-5$ disc space in a 37 -year-old patient with pseudarthrosis, who 18 months previously had undergone a PLIF, is stained with $\mathrm{H}$ \& E. Section demonstrates new bone formation adjacent to old bone resorption (outlined). Multinucleated osteoclasts (arrowheads) are identified within the interstitial bone matrix. Osteoblasts (arrows) line an area of newly formed bone containing embedded osteocytes.

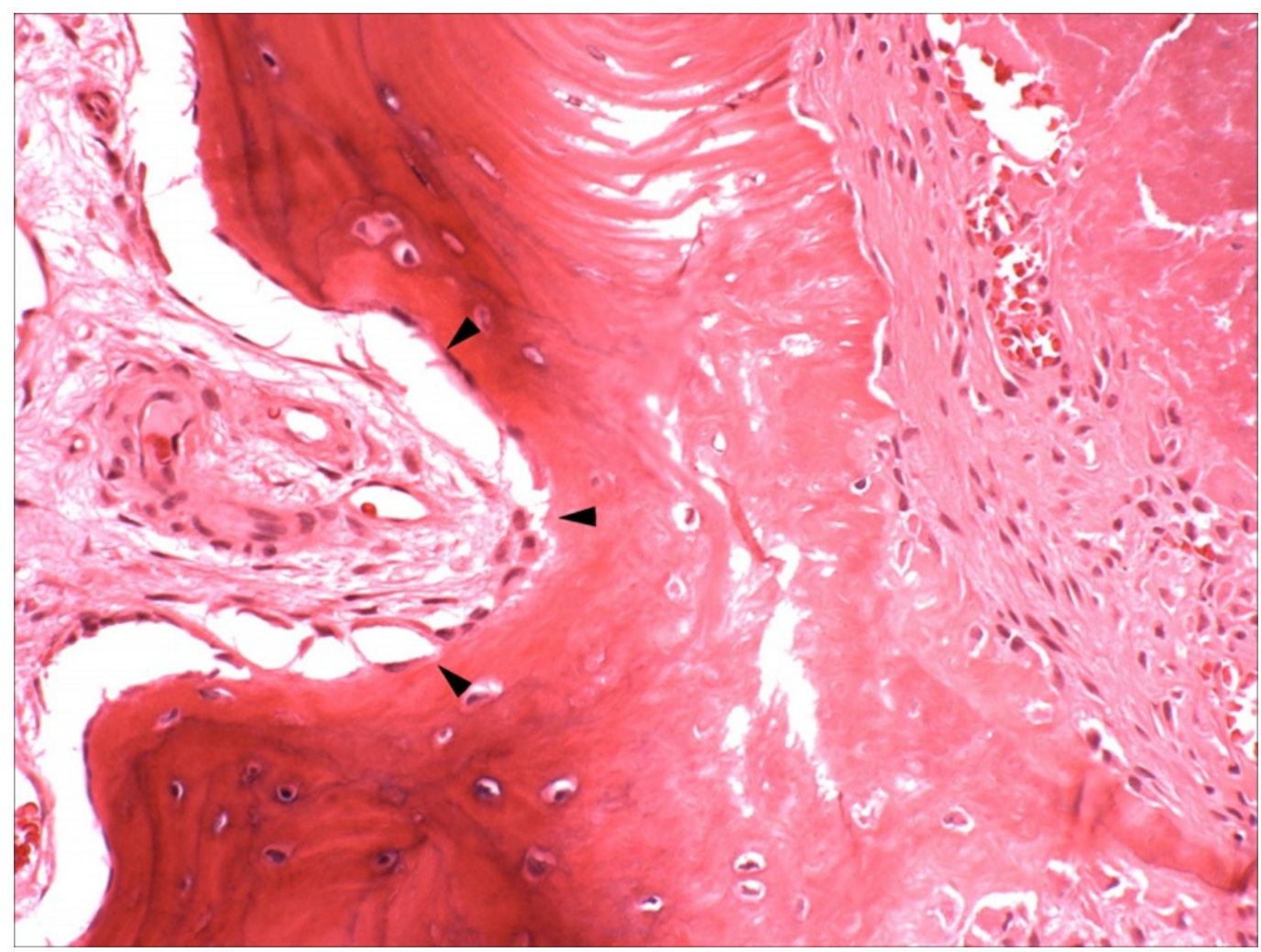




\section{FIGURE 2: Appositional New Bone Formation in Allograft, 400x magnification}

H \& E stain of another area of actively remodeling allograft shows cutting cone on the right invading dead bone of the allograft with another cone on the left demonstrating osteoblastic new bone formation layering on remnants of nonviable, original allograft in the center.

Eight major and six minor complications occurred among the entire patient series of 339 PLIF operations ( $2 \%$ each). This $4 \%$ total complication rate was relatable to the patients and the operations performed (not discussed in this paper) and not attributable to the functional qualities of the alloimplants processed at WTS. Details of these 14 complications will be reported in a paper in preparation.

\section{Discussion}

After Phillips and Kaye demonstrated the strong bactericidal activity of ethylene oxide (EO) in 1949 [13], numerous reports cited its effectiveness in sterilizing catheters, anesthesia equipment, tissue culture media, arterial grafts, and dural and bone grafts [10, 14-18]. By 1969, its virucidal effect was shown against hepatitis virus [19-20]. In the four decades after the discovery of its bacteriocidal effect during which EO was used as an industrial fumigant, the toxic effects of this substance and its reaction products in tissue, ethylene chlorohydrin (EC), and ethylene glycol (EG), were reported in organs and tissues [11, 21-26]. By the mid-1970s, sporadic papers had reported the use of EO in the sterilization of bone and dura mater, but no studies had validated its diffusion into and out of tissues, nor had demonstrated its effectiveness in destroying surface and interstitial microorganisms, nor had reported the removal of EO, EC, and EG toxic residues after tissue processing [14-17, 27-29].

Between 1977-1979 at the NSTL, gaseous EO was comprehensively studied for its effectiveness in surface and interstitial sterilization of tissues, the kinetics of diffusion of EO into and extraction from tissue, the formation of reaction products EC and EG, and the effectiveness of lyophilization and subsequent aeration in the removal of residues from tissues [10]. In 1980, the report of these laboratory studies stipulated the following: (1) that gaseous EO is a very effective surface sterilant of wet bone, dura mater, and fascia and does not grossly alter tissue morphology; (2) that EO partially penetrates through compact bone before lyophilization but requires serial openings in compact bone to maximize its bactericidal penetration and effectiveness through wet bone, a goal invariably achieved in grafts; (3) in order to achieve these results, that before sterilization with EO, bone must be vigorously irrigated with water (a) to rid it of cellular components that can elicit a strong immune response to the implant and block penetration of EO and desorption of EO, EC, and EG, (b) to remove these cellular elements which serve as mechanical barriers to the prompt revascularization of the transplanted graft, the first step of remodeling and incorporation of the graft into the patient's skeleton, and (c) to reduce the levels of chloride ions which serve as substrates for formation of EC during the sterilization cycle; (4) that lyophilization of EO sterilized tissues over 72-120 hours effectively reduces concentrations of EO, EC, and EG to the levels compliant with the FDA standard for maximal acceptable residuals of these compounds within implanted devises or tissues [10].

Transplantation medicine's hallmark is successful human anatomical and functional restoration. Overarching goals of tissue transplantation are the safe and effective utilization of human tissues that reclaim for the patient the anatomic integrity of a compromised body part with return of a functional competence free of pain or other debilitating symptoms. Recordation of our procedures for obtaining, processing, distributing, and surgically 
applying tissues is reported herein to memorialize a successful methodology of human tissue processing now enigmatically repudiated by tissue banks in the United States. Over the 18-year period of providing over 50,000 human tissue implants for surgeons in the United States, all of which were terminally sterilized with ethylene oxide, NSTL/WTS received no reports from surgeons, hospitals, or any other source of allografts of bone or soft tissue causing an infection or neoplasm in proximity to or distant from the alloimplant.

Although the rate of return of favorable reports of allografts to NSTL/WTS from operating surgeons or hospitals was $50 \%$ or more, the likelihood of an unreported infection or complication of the allograft per se would appear remote in this litigious society for two reasons: bone graft complications (infections, tumor causation) would cause the patient to incriminate potential medical malpractice by the surgeon or precipitate accusation of tissue processor violation of FDA standards or tissue bank negligence during processing as root causes of damages to the patient. The personal injury trial bar reminds the public on television daily of financial rewards accruing from complications of an operation reflecting either medical malpractice by the operating surgeon or violation of standards by providers of products. Moreover, infections, neoplasms or other adverse effects from utilization of grafts would very likely be promptly reported to the tissue processor by treating surgeons in an effort to displace culpability from themselves to the tissue-processing laboratory as a target of patient litigants. Absence of adverse reports from user surgeons, hospitals and patient-recipients of allografts, therefore, likely reflects absence of complications incident to their use. The suspected inefficiency of passive reporting would transmute to invigorated active reporting in the presence of complications from use of allografts in contemporary American society.

In 2005, the Food and Drug Administration (FDA) implemented rules requiring tissue banks to report to the FDA infections after allograft transplantations. From 2006 through June 2010, 436 infections were reported (97/year) from a population of 1,500,000-transplanted tissues/year over five years (7,500,000 total tissues transplanted). Some infections were not necessarily due to the allograft but to other complicating factors of the operation. Organisms reported included bacteria (62\%), fungi (8.3\%), viruses (11\%), prions (1.4\%), and "unknown" (17.7\%) [4]. The likelihood of an allograft causing an infection seemed infinitesimal in that report, $436 / 7,500,000=(0.00006=0.006 \%)$.

However, pathogenic infections from contaminated tissues occur and can be devastating, leading to death of a recipient. Donor-to-recipient transmission of HIV, hepatitis, human T-cell lymphotropic virus, rabies, Herpes simplex virus, cytomegalovirus, fungus, and transmissible spongiform encephalopathy has occurred. Because of fatal and debilitating infections in tissue recipients, Eastlund has called for terminal sterilization in all tissues not dependent on cellular viability (bone, tendon, dura, pericardium) [30].

\section{Contemporary options for terminal sterilization of human tissue}

In a 2007 survey of accredited and non-accredited tissue banks in the United States by the American Association of Tissue Banks, 109 American and seven Canadian tissue banks participated [31]. Approximately 90\% of tissue banks did not expose tissues to irradiation prior to processing; pre-processing irradiation was used in about $10 \%$ of banks below $1.5 \mathrm{kGy}$ to reduce the initial bioburden. About half (47\%) did not treat tissues with irradiation as the final treatment, but utilized antimicrobials or various proprietary processing solutions or methodologies after the donor individuals' serological testing escaped detection of communicable diseases. Gamma irradiation only above $25 \mathrm{kGy}$ was practiced in $6.3 \%$ of reporting banks; gamma irradiation only between $15-25 \mathrm{kGy}$ was utilized in $37.5 \%$ of banks; gamma irradiation only below $15 \mathrm{kGy}$ was employed in $3.1 \%$ of banks; irradiation other than 
gamma irradiation was used in $6.3 \%$. Thus, a total of $53 \%$ of tissue banks terminally sterilized tissue with irradiation. No tissue bank used ethylene oxide for terminal sterilization.

Concomitant with an evolutionary majority of tissue processors utilizing irradiation for terminal sterilization of bone, the International Atomic Energy Agency (IAEA) has formulated a Code of Practice for the Radiation Sterilization of Tissue Allografts. These standards have been proposed to apply in all parts of the world [32-33].

Terminal sterilization of bone with ethylene oxide, a highly reactive gas that alkylates RNA, DNA and destroys microorganisms, is currently an abandoned methodology. An internal survey of tissue banks by the American Association of Tissue Banks in 1988 revealed two-thirds of banks in the United States used ethylene oxide and one-third used irradiation to sterilize tissues. Practices reversed by 1992 at which time a second survey by AATB revealed two-thirds irradiated and one-third used EO for terminal sterilization [34]. In the 2007 AATB Survey of 109 participating U.S. Tissue Banks, 32 processed bone. No facility used EO for terminal sterilization [31].

Irradiation at various doses and ethylene oxide can both achieve terminal sterilization of implants by effectively eliminating bacteria, fungi and viruses, but not prions. The Association for the Advancement of Medical Instrumentation, a standards-setting organization for the medical industry, has stipulated a sterility assurance level (SAL) as the probability of the survival of a living single microorganism following completion of a validated sterilization process [35]. The industrial guidelines apply to elimination of bacteria, fungi, and spores and require an overall reduction of microorganisms by $6 \log _{10}$ or the achievement of a SAL of $10^{-6}$, the probability of the presence of a living, contaminating microorganism following completion of the sterilization measures being 1 in 1,000,000 [36]. To achieve this degree of sterility, tissue banks must submit human tissues to sterilants, which penetrate but do not adversely affect tissues and compromise their biological and mechanical functions. Irradiation and EO must each be measured against these ideal properties of a tissue sterilant: achieve an SAL of $10^{-6}$, while not adversely altering mechanical and biological function.

\section{The argument for gamma irradiation}

Gamma irradiation is a very effective method of tissue sterilization. Irradiation is bactericidal and virucidal by two mechanisms: direct damage (ionization) to the DNA/RNA in the cell nuclei, causing defects, including genomic dysfunction and destruction, and interfering with reproduction; indirect damage from ionizations in the surrounding water causing hydroxyl and other free radicals to attack the DNA. Approximately 40\% of DNA damage is caused by direct injury and $60 \%$ by indirect action. Therefore, lyophilized material containing bacteria will be more radio-resistant to ionizing radiation than hydrated material. Viruses are more radioresistant than bacteria because of their smaller target size with fewer inactivation sites and better repair and restitution capabilities [37]. In the frozen or freeze-dried state, higher doses of irradiation must be delivered in the absence of the secondary generation of free radicals from tissue water.

A survey of tissue banks in 1996 revealed 10-35 kGy of irradiation was then being used to sterilize tissues [38]. Consensus on the optimum dose of irradiation has not been reached because of numerous variables and individual decisions by tissue banks, but standard irradiation doses currently continue to range between 15 to $35 \mathrm{kGy}$ [39]. The International Atomic Energy Agency (IAEA) recommends a standard dose of $25 \mathrm{kGy}$ for terminal sterilization [33]. In the United States, a radiation dose of $15 \mathrm{kGy}$ is sometime used to reduce the microbiological bioburden, not to inactivate all viruses [40]. Though bacteria and fungi in tissue are generally eliminated in doses $10-20 \mathrm{kGy}$, a dose of $89 \mathrm{kGy}$ is needed to inactivate the HIV 
virus from bone with a SAL of $10^{-6}$ [39-40]. Bienek, et al. demonstrated in 2007 that gamma irradiation at doses $25-40 \mathrm{kGy}$ is in itself insufficient as a sterilant for viruses [41].

\section{Biomechanical effects of gamma irradiation}

Gamma irradiation injures bone collagen directly in the dry state by splitting polypeptide chains and indirectly in the wet state from release of free radicals from water molecules, which secondarily cause cross-linking in bone matrix collagen [39, 42-43]. Consequently, there is a significant reduction in plastic properties of the bone (such as ultimate strength and toughness), rather than in elastic properties (such as stiffness and yield strength). Bone loses strength and becomes more brittle, though there are only minimal effects on Young's elastic modulus. Therefore, irradiation has little influence on the stiffness of bone, but brittleness is significantly increased [44]. Fatigue behavior of allografts is also dramatically increased after irradiation, which decreases the resistance of bone to crack propagation [45-46]. These effects are dose-dependent and not prevalent at lower doses of 15-20 kGy. A dose-response reduction occurs with irradiation in bone bending and torsion strength, and work-to-fracture with a significant non-linear loss in strength of cortical bone exposed to more than $30 \mathrm{kGy}$ [34, 4749].

It is for this reason that the lowest effective doses of irradiation have been proposed based on the determined bacterial bioburden of tissues following processing and before irradiation, in accord with accepted standards for sterilization promulgated by the medical device industry. Baker, Ronholdt, and Bogdansky have indicated a tissue implant achieves the FDA standard (SAL $10^{-6}$, a sterility assurance level indicating there is a one in one million chance of a product being non-sterile) with an irradiation dose of $9.2 \mathrm{kGy}$ [50]. Such a low dose of irradiation does not totally sterilize tissue of all microorganisms in that the viral DNA is considerably more radioresistant.

The physical effects of exposure of bone to gamma irradiation at levels $20 \mathrm{kGy}$ and above can translate into clinical results when such grafts provide structural support. One major academic orthopedic service transplanted 282 large allografts that received no radiation, 24 that received dosages between 10-30 kGy, and compared the results. In the non-irradiated group, $11 \%$ developed an infection, $18 \%$ a fracture and $19 \%$ a non-union. There were no infections in the radiated group, 39\% developed a fracture and $7 \%$ resulted in a non-union. In this direct comparison, terminal sterilization with gamma irradiation prevented infections, reduced nonunion by more than half, but more than twice the percent of irradiated allografts fractured compared to non-irradiated allografts (9 of 24 allografts fractured (38\%) versus 51 of 282 (18\%) non-irradiated controls, $p=0.03$ Fisher's exact test). Authors did not stipulate specific radiation exposures of individual long bone grafts in the series but only the range of doses cited above. One cannot determine whether any or some of these fractured allografts had been irradiated with a dose less than $20 \mathrm{kGy}$, the reported dose above which irradiation consistently causes damage to the collagen within bone [51].

Zheng, et al. in 2005 reported the mechanical properties of human cortical bone following gamma irradiation: reductions of ultimate 3-point bending stress were $6 \%$ at $15 \mathrm{kGy}, 23 \%$ at 25 $\mathrm{kGy}$, and $30 \%$ at $50 \mathrm{kGy}$; reductions in toughness were $12 \%$ at $15 \mathrm{kGy}, 13 \%$ at $25 \mathrm{kGy}$, and $22 \%$ at $50 \mathrm{kGy}$; ultimate compressive stress was not significantly reduced by doses below $50 \mathrm{kGy}$ [52]. Zhou, et al. in 2011 reported major decrements in shear, bending, and compression strength of cortical bone from mature goat tibias subjected to $25 \mathrm{kGy}$ gamma irradiation at room temperature [53] (see Discussion below).

\section{Biological effects of gamma irradiation -- osteoinduction}

In the early 1960s, Marhall Urist at UCLA in a landmark discovery identified an extractable 
protein in bone he first named the bone induction principle [54] and later called the bone morphogenetic protein (BMP) for its ability to transform undetermined pluripotential mesenchymal cells into a determined osteoblastic cell lineage. Over his career, he continually refined knowledge of BMP [55]. Bone contains very small quantities of BMP $(1 \mathrm{mg} / \mathrm{kg}$ wet weight of fresh cortical bone) [55]. In 1988, Wozney, et al. reported cloning and expressing recombinant bone morphogenetic proteins, which surgeons have used to augment bone formation, for example, in lumbar fusions [56].

The literature is inconsistent and enigmatic on the effects of irradiation on osteoinductive growth factors present in bone, such as BMP and transforming growth factor- $\beta$ (TGF- $\beta$ ). The collagen carrier appears more labile to gamma irradiation than the BMP itself [39, 42, 57]. Buring and Urist showed bone induction was eliminated when allografts were irradiated at doses between 20-40 kGy, but also lost during delayed collection time, heating over $60^{\circ} \mathrm{C}$, and exposure to chemicals hydroperoxide, beta-propiolactone, and thrice freezing and thawing (cryolysis) [58-59]. Munting, et al. and Voggenreiter, et al. demonstrated the injurious effects of irradiation on osteoinduction [60-61]. Other investigators (Wientroub and Reddi in 1988, Glowacki in 2005 and Hallfeldt, et al. in 1995) found doses of irradiation between 20-50 kGy did not eliminate osteoinduction [62-64]. Destructive effects from irradiation of bone on its capacity for osteoinduction have not been reported in every study, but differences in experimental protocols may explain variations in results among them [39, 65].

Bone is the richest source of transforming growth factor b (TGF-b) in the body at a level of 200 mg per kg of wet weight, and this growth factor enhances bone formation and healing [66]. In 1993, Puolakkainen, et al. reported the effects of exposure to irradiation and ethylene oxide on the TGF-b levels in samples of human femoral heads removed during hip reconstruction operations from five patients with mean age of 70 years. Bone tissue was ground in a bone mill to a large-particle size, demineralized and divided into three groups: untreated, irradiated with 16-19 kGy gamma irradiation, or sterilized in a $12 \%$ ethylene oxide sterilizer at $60^{\circ} \mathrm{C}$. Bone samples were then assayed for TGF-b. Whereas direct exposure of carrier-free, purified recombinant TGF-b to ethylene oxide at $60^{\circ} \mathrm{C}$ totally destroyed this growth factor, irradiation of this purified TGF-b directly had no effect on TGF-b levels. However, TGF-b in demineralized bone was not significantly diminished by either ethylene oxide or irradiation sterilization [66]. Other studies have demonstrated the high temperature of EO sterilization exposure $\left(60^{\circ}\right.$ C) to this recombinant TGF-b might have contributed to the lowering its level in the purified sample [65]. Neither low-dose irradiation or EO sterilization of ground bone with large particles (in contrast to bone powder) adversely affected TGF-b content of bone, a major promoter of bone formation [66].

It is likely demineralized bone matrix is osteoinductive in rodents, but not in primates. The small amounts of BMP and growth factors in compact bone probably explain the absence of provable osteoinduction in human allografts. Aspenberg, et al. demonstrated osteoinduction from defatted, demineralized allogeneic bone matrix from rat fibulae but not from the fibulae of squirrel monkeys [67]. In addition, the lead author implanted demineralized matrix in his own thigh, which was obtained from two different young human donors. At four months, the implant was partly resorbed and no cartilage or bone was found in histological sections.

Allografts in humans are only osteoconductive, providing a scaffold for revascularization and appositional new bone formation. Commercial demineralized human bone preparations ("putties") have never been provably osteoinductive in humans, but likely provide a space-filler function to be replaced over time when successful through osteoconductive remodeling. Glowacki concluded that the performance of different samples of demineralized bone allografts tested in vivo or in vitro systems cannot be used as a measure of clinical performance [63]. 


\section{The argument for ethylene oxide sterilization}

Ethylene oxide (EO) is a highly reactive, diffusible gas, which achieves terminal sterilization of bone and soft tissues through alkylation of nucleophilic $\mathrm{N}$-groups in the purine and pyrimidine bases of RNA and DNA and thereby destroys bacteria, fungi, and viruses, but not prions. Early experimentation and clinical practice supported its use in sterilizing human bone and soft tissues [10, 68-74].

\section{Biomechanical effects of ethylene oxide sterilization}

Ethylene oxide has been compared directly with gamma irradiation for its biomechanical effects on bone torsion, three-point bending, and compression. Zhou, et al. in 2011 demonstrated a gamma irradiation dose of $25 \mathrm{kGy}$ reduces goat tibial maximal shear modulus by $48 \%$, shear stress by $55 \%$, deflection by $71 \%$, bending stress by $51 \%$, bending strain by $74 \%$, extension by $60 \%$, and compression strain by $50 \%$. In comparison, frozen only sterile bone or ethylene oxide sterilized bone had no effect on any of these parameters of torsion, three-point blending, and compression strength [53]. There have been no studies implicating an injurious effect on the mechanical properties of bone or soft tissues resulting from sterilization with ethylene oxide [74].

\section{Biological effects of ethylene oxide sterilization -- osteoinduction}

Despite the early favorable reports supporting EO for terminal sterilization of hard and soft tissues, there followed critiques of this methodology in rodent studies from Munting, et al. in 1988 [60] and Aspenberg, et al. in 1990, which indicated EO destroyed bone induction in a dose-dependent manner [75]. Aspenberg and Lindquist persisted in this critique in 1998 [76], and Thoren with Aspenberg in 1995 even found EO impaired osteoconductive remodeling in the laboratory rat [77]. A further investigation by Zhang, et al. in 1997 reported from the same laboratory as the earlier Munting, et al. research. The publication contradicted the earlier investigations in that laboratory to demonstrate ethylene oxide sterilization of chloroformmethanol defatted, freeze-dried bone does not extinguish the osteoinductive capacity of demineralized bone in the rat model when sterilized at a temperature of $40^{\circ} \mathrm{C}$ [65].

Information from rodent studies is not invariably transferable to higher animals. There is no evidence that allogeneic demineralized bone is osteoinductive in orthotopic sites in large mammals, including primates $[67,78]$.

When ethylene oxide is used as a sterilant, it is imperative that measures are undertaken to remove the EO and its byproducts, EC and EG, from bone and soft tissues. Jackson, et al. reported the presence of ethylene chlorohydrin in the synovial fluid of intra-articular bonepatellar tendon-bone allografts in seven of 109 (6.4\%) of their patients undergoing reconstruction of the anterior cruciate ligment [79]. Tissue processing laboratories must perform regular screening for EO, EC, and EG residuals in bone and soft tissues. Methods should be introduced to rid the grafts of these chemicals when present, as described by Kaku, et al. [80].

\section{Conclusions}

A decision in the early 1970s at NSTL to pursue the terminal sterilization of bone with ethylene oxide was based on knowledge available at that time and repeatedly confirmed since then, that such a method would be an effective sterilant and safe in minimizing damage to the structure and biological integrity of bone, would be an efficient and safe methodology for a tissue processing laboratory, and most importantly, would be efficacious and safe for human allograft 
recipients. Other investigations by Kearney et al. in 1993 and Kakiuchi, et al. in 1996 subsequently confirmed our findings [81-83]. Four decades of clinical experience since then have confirmed the wisdom of that decision to sterilize tissues with ethylene oxide rather than with gamma-irradiation.

Terminal sterilization of bone with ethylene oxide is currently an abandoned methodology. This paradoxical total apostasy from ethylene oxide sterilization in the United States described previously has proceeded pari passu with the maturation and commercialization of the tissue banking industry in an evolution from its scientific inception and from the pioneering contributions originating from the mid-twentieth century. Such a dramatic receptivity and adoption of sterilization by irradiation in the United States also appears to accept the incomplete sterilization of viruses in order to avoid the mechanical and biological damage done to tissue grafts by irradiation at levels that are virucidal, as well as bactericidal and fungicidal. Emphasis by the tissue banking community seems to have focused on accommodating by various techniques to the limitations of gamma irradiation. Consensus on the optimal dose of irradiation has not been reached because of numerous variables and individual decisions by banks, but irradiation doses ranging from 15 to $35 \mathrm{kGy}$ do not extinguish viruses with a SAL of $10^{-6}$ and at higher levels on this scale, embrittle and weaken bone. A reliance on low doses of irradiation to reduce the bioburden of microbes with gamma irradiation has become accepted dogma, rather than seizing upon the advantages of ethylene oxide for sterilization of tissues [84-87].

This apparent dismissal of tissue sterilization with ethylene oxide by the tissue banking community in the United States must be reconsidered in view of this method's confirmed efficacy and safety over four decades in thousands of patients. The one paper by Jackson, et al. in 1990 demonstrating retained ethylene chlorohydrin in the knee joints in seven of 109 patients (6.4\%) undergoing reconstruction of the anterior cruciate ligament [79] appears in retrospect to have been alarming, pivotal, and transformative, leading to the subsequent abandonment of EO sterilization of tissues by the tissue banking community. The WTS laboratory meticulously processed bone which subsequently contained little or no EO, EC, or EG. Soft tissues sometimes contained marginal levels of these molecules, but invariably below the FDA recommended limits. There were never reports of reactions in patient recipients. Because of its superior sterilization capacities when properly administered without compromising the biomechanical and biological capacities of allografts, ethylene oxide must be reconsidered and scientifically reinvestigated for terminal sterilization of tissues.

Information reported above demonstrates the following: (1) EO has no injurious effect on mechanical strength of bone grafts; irradiation causes a dose-dependent decrease in mechanical properties of allogeneic bone at levels above $20 \mathrm{kGy}$ that is variable, dependent on various conditions of exposure and delivery, such as temperature, injures collagen and can lead to fractures. (2) EO eliminates all bacteria, fungi, and viruses; high doses of irradiation are required to eradicate all viruses with consequential major weakening of the allograft.

The Navy Tissue Bank closed at the National Naval Medical Center in Bethesda MD in 1989. Its myriad accomplishments have been previously published [6-7]. In 1996, the NeuroSkeletal Transplantation Laboratory/Western Transplantation Services suspended operations. With this publication, the record of NSTL/WTS, a collateral beneficiary of the pioneering contributions, leadership and financial support of the Navy Tissue Bank and the Office of Naval Research, is acknowledged and documented with refulgent gratitude to the exceptional mentorship of Kenneth Sell, MD, Ph.D. and Marshall Urist, M.D.

\section{Additional Information}




\section{Disclosures}

Human subjects: Consent was obtained by all participants in this study. The Board of Directors of The Institute for Medical Research issued approval The Board of Directors of IMR approved the research conducted on the sterilization of human tissue and the provision of humanderived tissue for surgical implantation in humans between 1972-1990. The authors declare they have no competing interests. WTS closed in 1996. During the course of its existence, Doctor Prolo never received any financial benefits from NSTL/WTS. Doctor Oklund was the Director and Mr. Borer was a technician at WTS and received salaries. Animal subjects: All authors have confirmed that this study did not involve animal subjects or tissue. Conflicts of interest: In compliance with the ICMJE uniform disclosure form, all authors declare the following: Payment/services info: Research described in this paper was conducted at the Institute for Medical Research (IMR) in San Jose CA (subsequently called California Institute for Medical Research, CIMR in about 1989). Between 1975-1979 investigations were supported in part by Office of Naval Research Contract N00014-76-C-0621. Financial relationships: Mark Borer declare(s) an alternate financial activity from Western Transplantation Services. Certified transplant technician. Sally Oklund declare(s) an alternate financial activity from Neuroskeletal Transplantation Laboratory and Western Transplantation Services. Director. Donald Prolo declare(s) an alternate financial activity from Neuroskeletal Transplantation Laboratory and Western Transplantation Services 1972-1996. Medical Director without pay. Mark Borer declare(s) an alternate financial activity from California Transplant Donor Network. Director of Quality Systems. Other relationships: All authors have declared that there are no other relationships or activities that could appear to have influenced the submitted work.

\section{Acknowledgements}

Author Contributions: DJP: submitting author, surgeon for lumbar fusions; patient information; manuscript preparation; SAO: collating and analysis of patient information; manuscript preparation. MB: tissue collection, processing and quality control; manuscript preparation. Acknowledgements: This investigation was supported in part by Office of Naval Research Contract N00014-76-C-0621

\section{References}

1. Younger EM, Chapman MW: Morbidity at bone graft donor sites. Journal of Orthopaedic Trauma. 1989, 3:192-5.

2. Macewen W: Observations concerning transplantation of bone. Proceedings of the Royal Society of London. 1881, 32:232-47.

3. Sullivan MT, Cotten R, Read EJ, Wallace EL: Blood collection and transfusion in the United States in 2001. Transfusion. 2007, 47:385-94.

4. Mallick TK, Mosquera A, Zinderman CE, St Martin L, Wise RP: Reported infections after human tissue transplantation before and after new Food and Drug Administration (FDA) regulations, United States, 2001 through June, 2010. Cell and Tissue Banking. 2012, 13:25967.

5. American Association of Tissue Banks: Standards of Tissue Banking. 13th ed. American Association of Tissue Banks, McLean, VA; 2012.

6. Strong DM: The US Navy Tissue Bank: 50 Years on the Cutting Edge . Cell and Tissue Banking. 2000, 1:9-16.

7. Hyatt GW: The founding of the U.S. Navy Tissue Bank. Transplantation Proceedings. 1976, 8:17-20.

8. Malinin TI: University of Miami Tissue Bank: collection of postmortem tissues for clinical use and laboratory investigation. Transplantation Proceedings. 1976, 8:53-8.

9. Smith MF: Northern California Transplant Bank . Transplantation Proceedings. 1976, 8:59-61.

10. Prolo DJ, Pedrotti PW, White DH: Ethylene oxide sterilization of bone, dura mater, and fascia lata for human transplantation. Neurosurgery. 1980, 6:529-39.

11. Ethylene oxide, ethylene chlorohydrin, and ethylene glycol: proposed maximum residue limits 
and maximum levels of exposure. Federal Register. 1978, 43:27473-83.

12. Cloward RB: The treatment of ruptured lumbar intervertebral discs by vertebral body fusion. I. Indications, operative technique, after care. Journal of Neurosurgery. 1953, 10:154-68.

13. Phillips CR, Kaye S: The sterilizing action of gaseous ethylene oxide; A review. American Journal of Hygiene. 1949, 50:270-9.

14. Sutherland TW, Williamson GM, Zinnemann K, Shucksmith HS: Graft sterilization; a bacteriological and histological study of the relative merits of ethylene oxide and betapropiolactone as tissue sterilizing agents, with special reference to arterial grafts. British Medical Journal. 1958, 1:734-6.

15. Snyder CC, Wardlaw E, Kelly N: Gas sterilization of cartilage and bone implants. Plastic and Reconstructive Surgery and the Transplantation Bulletin. 1961, 28:568-76.

16. Savelyev VI: The application of gaseous ethyleneoxide for sterilization of tissue grafts, obtained without maintaining sterile conditions. Acta Chirurgiae Plasticae. 1975, 17:198-204.

17. Rosomoff HL, Malinin TI: Freeze-dried allografts of dura mater - 20 years experience . Transplantation Proceedings. 1976, 8:133-8.

18. Mendes GC, Brandao TR, Silva CL: Ethylene oxide sterilization of medical devices: a review . American Journal of Infection Control. 2007, 35:574-81.

19. Miller WV, Walsh JH, Paskin S: Ethylene oxide sterilization to prevent post-transfusion hepatitis. NEJM. 1969, 280:386.

20. Jordy A, Hoff-Jorgensen R, Flagstad A, Lund E: Virus inactivation by ethylene oxide containing gases. Acta Veterinaria Scandinavica. 1975, 16:379-87.

21. Hollingsworth RL, Rowe VK, Oyen F, McCollister DD, Spencer HC: Toxicity of ethylene oxide determined on experimental animals. AMA. 1956, 13:217-27.

22. Bruch CW: Gaseous sterilization. Annu Rev Microbiol. 1961, 15:245-62.

23. Hine $\mathrm{CH}$, Rowe, V. K: Ethylene oxide. Industrial Hygiene and Toxicology. Patty FA (ed): Interscience, New York; 1962. 1626-35.

24. Andersen SR: Ethylene oxide toxicity. A study of tissue reactions to retained ethylene oxide . The Journal of Laboratory and Clinical Medicine. 1971, 77:346-56.

25. Mc Gunnigle RG, Renner JA, Romano SJ, Abodeely RA, Jr: Residual ethylene oxide: levels in medical grade tubing and effects on an in vitro biologic system. Journal of Biomedical Materials Research. 1975, 9:273-83.

26. Phillips CR: Gaseous sterilization. Disinfection, Sterilization, and Preservation. Block SS (ed): Lea \& Febiger, Philadelphia; 1977. 592-610.

27. Egyedi P, van Palenstein Helderman WH: Sterilization of infected bone by lyophilization and rehydration with antibiotic solutions. Journal of Maxillofacial Surgery. 1976, 4:65-6.

28. Sharkey PC, Usher FC, Robertson RC, Pollard C, Jr.: Lyophilized human dura mater as a dural substitute. Journal of Neurosurgery. 1958, 15:192-8.

29. Stern WE: The surgical application of freeze-dried homologous dura mater . Surgery, Gynecology \& Obstetrics. 1958, 106:159-62.

30. Eastlund T: Bacterial infection transmitted by human tissue allograft transplantation . Cell and Tissue Banking. 2006, 7:147-66.

31. American Association of Tissue Banks: 2007 American Association of Tissue Banks annual survery of accredited tissue banks in the United States. McLean, VA; 2010.

32. Loty B: International standards for tissue banks. Sterilisation of tissues using ionising radiations. Kennedy JF, Phillips, G. O., Williams, P. A (ed): CRC Press LLC, Boca Raton; 2005. 3-38.

33. International Atomic Energy Agency: Radiation sterilization of tissue allografts: requirements for validation and routine control. A code of practice. International Atomic Energy Agency, Boston; 2002.

34. Vangsness CT, Jr., Garcia IA, Mills CR, Kainer MA, Roberts MR, Moore TM: Allograft transplantation in the knee: tissue regulation, procurement, processing, and sterilization. The American Journal of Sports Medicine. 2003, 31:474-81.

35. Association for the Advancement of Medical Instrumentation: Sterilization of health care products - general requirements for characterization of a sterilizing agent and the development, validation, and routine control of a sterilization process for medical devices. Association for the Advancement of Medical Instrumentation, Arlington; 2000.

36. Pruss A, von Versen, R., Pauli, G: Viruses and their relevance for gamma irradiation sterilisation of allogenic tissue transplants. Sterilisation of tissues using ionising radiations. 
Kennedy JF, Phillips, G. O., Williams, P. A (ed): CRC Press LLC, Boca Raton; 2005. 235-54.

37. Hendry JH: Protective effects on micro-organisms in radiation sterilized tissues . Sterilisation of tissues using ionising radiations. Kennedy JF, Phillips, G. O., Williams, P. A (ed): CRC Press LLC, Boca Raton; 2005. 331-8.

38. Vangsness CT, Jr., Triffon MJ, Joyce MJ, Moore TM : Soft tissue for allograft reconstruction of the human knee: a survey of the American Association of Tissue Banks. The American Journal of Sports Medicine. 1996, 24:230-4.

39. Nguyen H, Morgan DA, Forwood MR: Sterilization of allograft bone: effects of gamma irradiation on allograft biology and biomechanics. Cell and Tissue Banking. 2007, 8:93-105.

40. Campbell DG, Li P: Sterilization of HIV with irradiation: relevance to infected bone allografts . The Australian and New Zealand Journal of Surgery. 1999, 69:517-21.

41. Bienek C, MacKay L, Scott G, et al.: Development of a bacteriophage model system to investigate virus inactivation methods used in the treatment of bone allografts. Cell and Tissue Banking. 2007, 8:115-24.

42. Dziedzic-Goclawska A, Kaminski A, Uhrynwska-Tyszkiewicz I, Stachowicz W: Irradiation as a safety procedure in tissue banking. Cell and Tissue Banking. 2005, 6:201-19.

43. Akkus O, Belaney RM, Das P: Free radical scavenging alleviates the biomechanical impairment of gamma radiation sterilized bone tissue. J Orthop Res . 2005, 23:838-45.

44. Currey JD, Foreman J, Laketic I, Mitchell J, Pegg DE, Reilly GC: Effects of ionizing radiation on the mechanical properties of human bone. J Orthop Res. 1997, 15:111-7.

45. Akkus O, Belaney RM: Sterilization by gamma radiation impairs the tensile fatigue life of cortical bone by two orders of magnitude. J Orthop Res. 2005, 23:1054-8.

46. Mitchell EJ, Stawarz AM, Kayacan R, Rimnac CM : The effect of gamma radiation sterilization on the fatigue crack propagation resistance of human cortical bone. The Journal of Bone and Joint Surgery. 2004, 86:2648-57.

47. Loty B, Courpied JP, Tomeno B, Postel M, Forest M, Abelanet R: Bone allografts sterilised by irradiation. Biological properties, procurement and results of 150 massive allografts. International Orthopaedics . 1990, 14:237-42.

48. Pelker RR, Friedlaender GE, Markham TC: Biomechanical properties of bone allografts. Clin Orthop Relat Res. 1983, 174:54-7.

49. Shelton WR, Treacy SH, Dukes AD, Bomboy AL: Use of allografts in knee reconstruction: II. Surgical considerations. J Am Acad Orthop Surg. 1998, 6:169-75.

50. Baker TF, Ronholdt CJ, Bogdansky S: Validating a low dose gamma irradiation process for sterilizing allografts using ISO 11137 method 2B. Cell and Tissue Banking. 2005, 6:271-5.

51. Lietman SA, Tomford WW, Gebhardt MC, Springfield DS, Mankin HJ: Complications of irradiated allografts in orthopaedic tumor surgery. Clin Orthop Relat Res. 2000, 375:214-7.

52. Zheng MH, Power RA, Openshaw JN, Price RI, Day RE, Winter J, Cowie A, Wood DJ: Effect of gamma irradiation on the mechanical properties of human cortical allograft bone. Sterilisation of tissues using ionising radiations. Kennedy JF, Phillips GO, Williams PA (ed): CRC Press LLC, Boca Raton; 2005. 141-9.

53. Zhou Z, Qin T, Yang J, Shen B, Kang P, Peil F: Mechanical strength of cortical allografts with gamma radiation versus ethylene oxide sterilization. Acta Orthopaedica Belgica. 2011, 77:6705 .

54. Urist MR: Bone: Formation by autoinduction. Science. 1965, 150 :893-9.

55. Urist MR, Sato K, Brownell AG, et al.: Human bone morphogenetic protein (hBMP). Proc Soc Exp Biol Med. 1983, 173:194-9.

56. Wozney JM, Rosen V, Celeste AJ, et al.: Novel regulators of bone formation: molecular clones and activities. Science. 1988, 242:1528-34.

57. Ijiri S, Yamamuro T, Nakamura T, Kotani S, Notoya K: Effect of sterilization on bone morphogenetic protein. J Orthop Res. 1994, 12:628-36.

58. Buring K, Urist MR: Effects of ionizing radiation on the bone induction principle in the matrix of bone implants. Clin Orthop Relat Res. 1967, 55:225-34.

59. Urist MR, Silverman BF, Buring K, Dubuc FL, Rosenberg JM: The bone induction principle. Clinical Orthopaedics and Related Research. 1967, 53:243-83.

60. Munting E, Wilmart JF, Wijne A, Hennebert P, Delloye C: Effect of sterilization on osteoinduction. Comparison of five methods in demineralized rat bone. Acta Orthopaedica Scandinavica. 1988, 59:34-8.

61. Voggenreiter G, Ascherl R, Blumel G, Schmit-Neuerburg KP: Extracorporeal irradiation and 
incorporation of bone grafts. Autogeneic cortical grafts studied in rats. Acta Orthopaedica Scandinavica. 1996, 67:583-8.

62. Wientroub S, Reddi AH: Influence of irradiation on the osteoinductive potential of demineralized bone matrix. Calcified Tissue International. 1988, 42:255-60.

63. Glowacki J: A review of osteoinductive testing methods and sterilization processes for demineralized bone. Cell and Tissue Banking. 2005, 6:3-12.

64. Hallfeldt KK, Stutzle H, Puhlmann M, Kessler S, Schweiberer L: Sterilization of partially demineralized bone matrix: the effects of different sterilization techniques on osteogenetic properties. The Journal of Surgical Research . 1995, 59:614-20.

65. Zhang Q, Cornu O, Delloye C: Ethylene oxide does not extinguish the osteoinductive capacity of demineralized bone. A reappraisal in rats. Acta Orthopaedica Scandinavica. 1997, 68:104-8.

66. Puolakkainen PA, Ranchalis JE, Strong DM, Twardzik DR: The effect of sterilization on transforming growth factor beta isolated from demineralized human bone. Transfusion. 1993, 33:679-85.

67. Aspenberg P, Lohmander LS, Thorngren KG: Failure of bone induction by bone matrix in adult monkeys. J Bone Joint Surg Br. 1988, 70:625-7.

68. Prolo DJ: Use of transplantable tissue in neurosurgery . Clinical Neurosurgery. 1981, 28:40717.

69. Prolo DJ, Pedrotti PW, Burres KP, Oklund S: Superior osteogenesis in transplanted allogeneic canine skull following chemical sterilization. Clin Orthop Relat Res. 1982, 168:230-42.

70. Prolo DJ, Oklund SA: Sterilization of bone by chemicals . Osteochondral Allografts: Biology, Banking and Clinical Applications. Friedlaender GE, Mankin, H. J., Sell, K. W (ed): Little Brown and Company, Boston; 1983. 233-8.

71. Oklund SA, Prolo DJ, Gutierrez RV, King SE: Quantitative comparisons of healing in cranial fresh autografts, frozen autografts and processed autografts, and allografts in canine skull defects. Clin Orthop Relat Res. 1986, 205:269-91.

72. Dubuc FL, Urist MR: The accessibility of the bone induction principle in surface-decalcified bone implants. Clin Orthop Relat Res. 1967, 55:217-23.

73. Sato K, Urist MR: Induced regeneration of calvaria by bone morphogenetic protein (BMP) in dogs. Clin Orthop Relat Res. 1985, 197:301-11.

74. Bechtold JE, Eastlund DT, Butts MK, Lagerborg DF, Kyle RF: The effects of freeze-drying and ethylene oxide sterilization on the mechanical properties of human patellar tendon. The American Journal of Sports Medicine. 1994, 22:562-6.

75. Aspenberg P, Johnsson E, Thorngren KG: Dose-dependent reduction of bone inductive properties by ethylene oxide. J Bone Joint Surg Br. 1990, 72:1036-7.

76. Aspenberg P, Lindqvist SB: Ethene oxide and bone induction. Controversy remains . Acta Orthopaedica Scandinavica . 1998, 69:173-6.

77. Thoren K, Aspenberg P: Ethylene oxide sterilization impairs allograft incorporation in a conduction chamber. Clin Orthop Relat Res. 1995, 318:259-64.

78. Schwarz N, Schlag G, Thurnher M, Eschberger J, Dinges HP, Redl H: Fresh autogeneic, frozen allogeneic, and decalcified allogeneic bone grafts in dogs. J Bone Joint Surg Br . 1991, 73:78790.

79. Jackson DW, Windler GE, Simon TM: Intraarticular reaction associated with the use of freezedried, ethylene oxide-sterilized bone-patella tendon-bone allografts in the reconstruction of the anterior cruciate ligament. The American Journal of Sports Medicine. 1990, 18:1-10.

80. Kaku N, Tsumura H, Kataoka M, Taira H, Torisu T: Influence of aeration, storage, and rinsing conditions on residual ethylene oxide in freeze-dried bone allograft. J Orthop Sci . 2002, 7:238-42.

81. Kearney JN, Bojar R, Holland KT: Ethylene oxide sterilisation of allogenic bone implants . Clinical Materials. 1993, 12:129-35.

82. Kakiuchi M, Ono K, Nishimura A, Shiokawa H: Preparation of bank bone using defatting, freeze-drying and sterilisation with ethylene oxide gas. Part 1. Experimental evaluation of its efficacy and safety. International Orthopaedics. 1996, 20:142-6..

83. Kakiuchi M, Ono K: Preparation of bank bone using defatting, freeze-drying and sterilisation with ethylene oxide gas. Part 2. Clinical evaluation of its efficacy and safety. International Orthopaedics. 1996, 20:147-52.

84. Ronholdt CJ, Bogdansky S: Determination of microbial bioburden levels on pre-processed allograft tissues. Sterilisation of tissues using ionising radiations. Kennedy JF, Phillips, G. O., 


\section{Cureus}

Williams, P. A (ed): CRC Press LLC, Boca Raton; 2005. 311-8.

85. Ronholdt CJ, Bogdansky S, Baker TF: Establishing an appropriate terminal sterilization dose based upon post-processing, pre-irradiation bioburden levels on allograft tissue. Sterilisation of tissues using ionising radiations. Kennedy JF, Phillips GO, Williams PA (ed): CRC Press LLC, Boca Raton; 2005. 303-10.

86. Nguyen H, Morgan DA, Sly LI, Benkovich M, Cull S, Forwood MR: Validation of $15 \mathrm{kGy}$ as a radiation sterilisation dose for bone allografts manufactured at the Queensland Bone Bank: application of the VDmax 15 method. Cell and Tissue Banking. 2008, 9:139-47.

87. Nguyen H, Morgan DA, Forwood MR: Validation of $11 \mathrm{kGy}$ as a radiation sterilization dose for frozen bone allografts. The Journal of Arthroplasty. 2011, 26:303-8. 